\title{
EFEKTIVITAS SARI KURMA TERHADAP PENINGKATAN KADAR HEMOGLOBIN PADA IBU NIFAS DI WILAYAH UPT PUSKESMAS KERENG BANGKIRAI KOTA PALANGKA RAYA
}

\author{
Yessica Harnetacia'), Yuniarti²) \\ ${ }^{1}$ Politeknik Kesehatan Palangka Raya \\ ${ }^{2}$ Balai Pelatihan Kesehatan Provinsi Kalimantan Tengah \\ Email yessicaharnetacia31@gmail.com¹,yuniarti22@gmail.com²
}

\begin{abstract}
ABSTRAK
Latar Belakang: Anemia pada wanita masa nifas (pasca persalinan) juga umum terjadi, sekitar $10 \%$ dan $22 \%$ terjadi pada wanita post partum. Anemia terjadi jika kadar hemoglobin dalam darah rendah. Hemoglobin adalah zat pembawa oksigen dalam sel darah merah, jika terjadi gangguan sistem transportasi oksigen (misalnya anemia) akan menyebabkan tubuh sulit untuk bekerja. Untuk mengurangi angka anemia post partum dapat dilakukan dengan cara meningkatkan kadar hemoglobin, salah satunya yaitu dengan mengkonsumsi sari kurma yang dapat meningkatkan kadar hemoglobin. Tujuan: Penelitian ini adalah mengetahui efektivitas sari kurma terhadap peningkatan kadar hemoglobin pada ibu nifas di wilayah UPT Puskesmas Kereng Bangkirai Tahun 2020. Metode penelitian yang digunakan yaitu Pre Eksperimental, One Group Pretest Posttest design (satu kelompok pretest - posttest). Teknik pengambilan sampel yang digunakan yaitu Consecutive Sampling dengan sampel sebanyak 30 responden yang sudah memenuhi atau sesuai dengan kriteria inklusi. Uji statistik yang digunakan adalah uji T-Paired. Hasil yaitu kadar hemoglobin ibu nifas sebelum diberikan intervensi terendah yaitu $9.0 \mathrm{gr} \%$ dan tertinggi yaitu $11.7 \mathrm{gr} \%$, kemudian sesudah diberikan intervensi, kadar hemoglobin terendah pada ibu nifas yaitu $11.8 \mathrm{gr} \%$ dan tertinggi yaitu $14.7 \mathrm{gr} \%$. Pada uji T, didapatkan nilai $p$-value sebesar 0,000 atau $p$ value $<\alpha(0,005)$, ini menunjukkan bahwa ada pengaruh atau efektivitas sebelum dan sesudah pemberian sari kurma terhadap peningkatan kadar hemoglobin pada ibu nifas di wilayah UPT Puskesmas Kereng Bangkirai Kota Palangka Raya. Kesimpulan: Terdapat efektivitas sebelum dan sesudah pemberian sari kurma terhadap peningkatan kadar hemoglobin pada ibu nifas di wilayah UPT Puskesmas Kereng Bangkirai Kota Palangka Raya.
\end{abstract}

Kata Kunci: anemia, Hb, sari kurma, ibu nifas

Copyright (C) 2020 Jurnal Skala Kesehatan. Politeknik Kesehatan Banjarmasin All rights reserved

Corresponding Author:

Yessica Harnetacia Bapelkes Prov.Kal-Teng

Email yessicaharnetacia31@gmail.com 


\section{PENDAHULUAN}

Angka Kematian Ibu (AKI) di Indonesia masih tinggi dan belum mencapai target Millenium Development Goals (MDG's) tahun 2015. Survei Demografi dan Kesehatan Indonesia (SDKI) tahun 2012 melaporkan AKI sebesar 359 per 100.000 kelahiran hidup disebabkan oleh kehamilan, persalinan dan nifas. Angka ini masih cukup tinggi jika dibandingkan dengan negaranegara ASEAN (Profil Kesehatan Indonesia, 2014). Tingginya angka kematian ibu di Indonesia masih didominasi oleh tiga penyebab utama langsung yaitu perdarahan, hipertensi dalam kehamilan dan infeksi ( riskesdas. 2013). Sedangkan tidak langsung yaitu karena penyakit yang timbul selama kehamilan, persalinnan dan nifas. Seperti anemia, penyakit ginjal, hepatitis atau kecelakaan.

Perdarahan menempati urutan tertinggi sebagai penyebab kematian ibu sepanjang periode perinatal. Anemia merupakan salah satu akibat dari Perdarahan menempati urutan tertinggi sebagai penyebab kematian ibu sepanjang periode perinatal. Anemia nifas terjadi bila kadar hemoglobin $(\mathrm{Hb})$ dalam darahnya kurang dari 12,0\% sebagau akibat ekspansi volume plasma yang lebih besar dari pada peningkatan konsentrasi Hemoglobin dalam sel darah merah.

Masa post partum merupakan tantangan bagi banyak ibu yang baru melahirkan. Pemulihan dari proses melahirkan, belajar menjadi orang tua, dan mengurus diri sendir membutuhkan banyak energi. Menderita anemia pada masa post partum dapat membuat proses ini menjadi lebih sulit. Anemia pada wanita masa nifas (pasca persalinan) juga umum terjadi, sekitar $10 \%$ dan $22 \%$ terjadi pada wanita post partum. Anemia terjadi jika kadar hemoglobin dalam darah rendah. Hemoglobin adalah zat pembawa oksigen dalam sel darah merah, jika terjadi gangguan sistem transportasi oksigen (misalnya anemia) akan menyebabkan tubuh sulit untuk bekerja.

Untuk mengurangi angka anemia post partum dapat dilakukan dengan cara meningkatkan kadar hemoglobin, salah satunya yaitu dengan mengkonsumsi sari kurma yang dapat meningkatkan kadar hemoglobin, menurut penelitian Dwi Amalia (2018) yang menyatakan bahwa ekstrak buah kurma dapat meningkatkan kadar hemoglobin. Kombinasi buah kurma yang kaya kandungan glukosa, $\mathrm{Ca}, \mathrm{Fe}, \mathrm{Zn}, \mathrm{Cu}, \mathrm{P}$ dan niasin dengan palmyra yang kaya kandungan vitamin $\mathrm{A}$, Na dan $\mathrm{K}$ mampu memperbaiki kadar hemoglobin pada pasien anemia.

Hasil studi pendahuluan di Kota Palangka Raya menunjukan bahwa angka anemia di Puskesmas Kereng Bangkirai sebesar $30 \%$. Oleh karena itu, peneliti tertarik untuk meninjau lebih lanjut efektivitas pemberian sari kurma dengan kenaikan kadar hemoglobin pada ibu nifas. Hal ini ditinjau dari factor kandungan zat besi dan protein yang terdapat didalam sari kurma yang diberikan kepada ibu nifasss.

\section{BAHAN DAN METODE}

Desain penelitian yaitu Pre Eksperimental, One Group Pretest - Posttest design (satu kelompok pretest - posttest). Lokasi penelitian yaitu dilakukan di wilayah kerja UPT Puskesmas Kereng Bangkirai. Teknik pengambilan sampel yang digunakan yaitu Consecutive Sampling dengan sampel sebanyak 30 responden yang sudah memenuhi atau sesuai dengan kriteria inklusi. Bahan atau intervensi yang diberikan yaitu sari kurma dan menggunakan alat ukur Hemmometer digital untuk mengukur kada Hemoglobin pada ibu, lembar observasi dan form data responden yang disertai lembar persetujuan bersedia menjadi responden.

Tahapan penelitian dimulai setelah didapatkannya responden, kemudian kepada responden, dijelaskan tujuan penelitian, manfaat penelitian, kerahasiaan informasi yang diberikan responden kepada penelitian. Kemudian mengukur kadar Hemoglobin menggunakan Hemmometer digital, setelah didapatkan hasil, ibu nifas tersebut diberikan sari kurma dalam 
kemasan botol 330 gram dengan aturan yaitu diminum 2x1 sendok makan sehari dipagi dan malam hari. Setelah diberikan sari kurma selama 14 hari, kemudian diukur hemoglobin menggunakan hemommeter digital untuk mengetahui keberhasilan dalam mengkonsumsi sari kurma terhadap peningkatan kadar hemoglobin.

Setelah semua responden di dapat dan di coding, selanjutnya dilakukan analisis data yaitu menggunakan spss versi 2.0, analisis univariat dan bivariate yang menggunakan uji analisis $T$ paired.

\section{HASIL}

Penelitian ini telah dilaksanakan pada bulan Januari hingga dengan Maret 2020. Responden pada penelitian ini adalah ibu nifas $0-14$ hari yang berjumlah 30 responden. Penelitian ini menggunakan 1 kelompok intervensi. Intervensi yang diberikan yaitu berupa pemberian sari kurma. Intervensi ini diberikan dengan frekuensi 2 kali sehari selama 14 hari. Penilaian kadar hemoglobin dilakukan sebelum (pre-test) dan sesudah (post-test) intervensi dengan menggunakan alat ukur hemmometer digital.

1. Analisis Univariat Karakteristik Responden

Tabel.1.1 Distribusi frekuensi pengukuran kadar Hemoglobin sebelum dan sesudah diberikan intervensi pada ibu ibu nifas di wilayah kerja UPT Puskesmas Kereng Bangkirai.

\begin{tabular}{lllllll}
\hline \multirow{2}{*}{ Variabel } & \multicolumn{5}{c}{ Kadar Hemoglobin } \\
\cline { 2 - 7 } & \multicolumn{5}{c}{ Sebelum Intervensi } & \multicolumn{3}{c}{ Sesudah Intervensi } \\
\hline & $\mathrm{n}$ & $\%$ & mean & $\mathrm{n}$ & $\%$ & Mean \\
\hline $\begin{array}{l}\text { Terapi } \\
\text { Pemberian }\end{array}$ & 30 & 100 & 10,147 & 30 & 100 & 13,243 \\
Sari & & & & & & \\
Kurma & & & & & & \\
\hline Min & 9.0 & & & 11.8 & \\
\hline Max & 11.7 & & & 14.7 & \\
\hline Total & 30 & 100 & 30 & \\
\hline
\end{tabular}

Tabel 4.4 menunjukkan bahwa kadar hemoglobin ibu nifas sebelum diberikan intervensi terendah yaitu $9.0 \mathrm{gr} \%$ dan tertinggi yaitu $11.7 \mathrm{gr} \%$, kemudian sesudah diberikan intervensi, kadar hemoglobin terendah pada ibu nifas yaitu $11.8 \mathrm{gr} \%$ dan tertinggi yaitu $14.7 \mathrm{gr} \%$.

2. Analisis Bivariat karakteristik Responden

Penelitian efektivitas pemberian sari kurma terhadap peningkatan kadar hemoglobin pada ibu nifas di wilayah kerja UPT Puskesmas Kereng Bangkirai didapatkan sebagai berikut :

Tabel 1.2 Efektivitas pemberian sari kurma terhadap peningkatan kadar hemoglobin pada ibu nifas 


\begin{tabular}{l|c|c|c|c|c}
\hline \multirow{2}{*}{ Variabel } & \multicolumn{4}{|c}{ Kadar Hemoglobin } \\
\cline { 2 - 5 } & \multicolumn{2}{|c|}{ Sebelum Intervensi } & \multicolumn{2}{c}{ Sesudah Intervensi } & \multirow{2}{*}{-value } \\
\hline $\begin{array}{l}\text { Pemberian } \\
\text { Sari }\end{array}$ & SD & mean & SD & mean & \multirow{2}{*}{0,000} \\
\cline { 2 - 5 } Kurma & 6516 & 10,147 & 8161 & 13,243 & \multirow{2}{*}{} \\
\hline
\end{tabular}

Berdasarkan tabel 1.2 pada uji T, didapatkan nilai $p$-value sebesar 0,000 atau $p$ value $<\alpha(0,005)$, ini menunjukkan bahwa ada pengaruh atau efektivitas sebelum dan sesudah pemberian sari kurma terhadap peningkatan kadar hemoglobin pada ibu nifas di wilayah UPT Puskesmas Kereng Bangkirai Kota Palangka Raya, maka dapat disimpulkan bahwa $\mathrm{H}_{0}$ ditolak dan $\mathrm{H}_{\mathrm{a}}$ diterima yang artinya terdapat efektivitas antara kadar hemoglobin sebelum dan sesudah pemberian sari kurma.

\section{PEMBAHASAN}

Pemberian sari kurma terhadap peningkatan kadar hemoglobin pada ibu nifas, dilakukan dengan uji T, didapatkan nilai $p$-value sebesar 0,000 atau $p$-value $<\alpha(0,005)$, ini menunjukkan bahwa ada pengaruh atau efektivitas sebelum dan sesudah pemberian sari kurma terhadap peningkatan kadar hemoglobin pada ibu nifas di wilayah UPT Puskesmas Kereng Bangkirai Kota Palangka Raya.

Hemoglobin merupakan protein utama tubuh manusia yang berfungsi mengangkut oksigen dari paru-paru ke jaringan perifer dan mengangkut $\mathrm{CO}_{2}$ dari jaringan perifer ke paru-paru. Sintesis hemoglobin merupakan proses biokimia yang melibatkan beberapa zat gizi atau senyawa-antara. Proses sintesis ini terkait dengan sintesis heme dan protein globin (Maylina, 2010).

Menurut Soetjiningsih (2007), Penyebab rendahnya kadar hemoglobin dalam darah salah satunya adalah asupan yang tidak mencukupi. Asupan zat gizi sehari-hari sangat dipengaruhi oleh kebiasaan makan. Pengetahuan yang kurang menyebabkan remaja memilih makan diluar atau hanya mengkonsumsi kudapan. Penyebab lain adalah kurangnya kecukupan makan dan kurangnya mengkonsumsi sumber makanan yang mengandung zat besi, selain itu konsumsi makan cukup tetapi makanan yang dikonsumsi memiliki bioavaibilitas zat besi yang rendah sehingga jumlah zat besi yang diserap oleh tubuh kurang (Ikhmawati dkk, 2013).

Kurma memiliki kandungan yang bermanfaat bagi tubuh manusia. Nilai gizi yang terdapat dalam buah kurma dengan takaran 100 gram : energy sebanyak $251 \mathrm{kkal}, 18,27$ air, vitamin A 90 IU, Protein 2,81 gram, vitamin B1 0,046 mg, Karbohidrat 66,78 gram, Vitamin B2 0,059 mg, Serat 7,1 gram, Vitamin B3 1,134 mg, Gula 56,38 gram, Vitamin B5 0,525 mg, Total Lemak 0,35 gram, Vitamin B6 0,147 mg, Lemak Jenuh 0,0028 gram, Vitamin B9 17mcg, MUFA 0,0032 gram, PUFA 0,017, Vitamin C 0,4 mg, Vitamin E 0,04 mg, Vitamin K 2,4 mcg, Kalsium $35 \mathrm{mg}$, Zat Besi 0,91 mg, Beta Karoten $5 \mathrm{mcg}$, Magnesium $38 \mathrm{mg}$, fosfor 55 mg, Kalium 484 mg, lutein dan zaexantin 67 mcg, sodium $2 \mathrm{mg}$ dan seng 0,26 mg.

Sari kurma adalah kurma yang dihaluskan dan diambil sarinya yang berbentuk cair dengan konsistensi kental, berwarna hitam, terasa sangat manis dan mengandung zat gizi lengkap seperti buah kurma. Sediaan sari kurma dibuat agar memudahkan para ibu untuk mengkonsumsi sari kurma.

Sari kurma merupakan suplemen kesehatan yang lengkap yang teruat dari kurma pilihan. Di dalamnya terdapat senyawa untuk sumber energy yang sangat dibutuhkan oleh tubuh. Sari kurma, memiliki kandungan nutrisi yaitu air 16,5\%, protein 0,6\%, Lemak 0,22 \%, Karbohidrat 47,9 \%, Energi 330 kkal/100mg, Kalium 776, 8 mg/100g, dan Kalsium 32,5 mg/100g. Sementara komposisinya adalah buah kurma, fruktosa dan glukosa. Sari kurma ini dipercaya bisa meningkatkan kadar hemoglobin karena mengandung zat besi juga sumber energy yang diperlukan oleh tubuh. (Al Farsi, 2014). 
Penelitian ini sejalan dengan penelitian yang dilakukan oleh Wiulin Setiowati dkk (2018), dengan judul Pengaruh Sari Kurma Terhadap Peningkatan Kadar Hemoglobin lbu Hamil Trimester III. Bahwa terhadap pengaruh pemberian sari kurma terhadap peningkatan kadar hemoglobin pada ibu hamil dengan uji statistik Wilcoxon, dengan nilai $p$ value $<0,05(0,002)$. maka dapat disimpulkan terdapat pengaruh pemberian sari kurma terhadap peningkatan kadar hemoglobin pada ibu hamil.

Berdasarkan penelitian lainnya yang dilakukan lin Kusumawati (2016) dalam karya tulis ilmiahnya yang berjudul Penggunaan Sari Kurma Untuk Meningkatkan Kadar Hemoglobin Ibu Nifas. Terdapat kenaikan yang signifikan antara hemoglobin sebelum diberikan intervensi dan kadar hemoglobin setelah diberikan intervensi .

Kemudian penelitian yang dilakukan oleh Durrotun Munafiah dkk (2019) dengan judul Manfaat Pemberian Sari Kurma Dalam Meningkatkan Kadar Hb Ibu Post Partum, mengatakan adanya pengaruh kadar $\mathrm{Hb}$ sebelum dan sesudah diberikan intervensi. metode yang digunakan adalah quasy eksperiment dengan rancangan pre-post two treatment, menunjukkan nilai $p$ value sebesar 0,000 yaitu $<0,005$.

Kemudian dari hasil literatur review yang dipaparkan oleh Alfiah Rahmawati dkk (2019) dengan judul Pengaruh Konsumsi Kurma Terhadap Kenaikan Kadar Hemoglobin : A Review menyimpulkan bahwa dari ketujuh hasil penelitian yang telah dilakukan, ada satu jurnal yang mengatakan bahwa tidak ada pengaruh kenaikan hemoglobin yang mengkonsumsi kurma maupun sari kurma. sedangkan jurnal lainnya mengatakan adanya pengaruh mengkonsumsi kurma maupun sari kurma dapat meningkatkan kadar hemoglobin. Hasil rata - rata hemoglobin sebelum diberikan kurma yaitu anemia ringan, namun setelah diberikan kurma atau sari kurma rata - rata hemoglobin meningkat.

Kurma maupun sari kurma dapat dikategorikan sebagai salah satu alternativ pilihan dalam memenuhi kebutuhan zat besi selama kehamilan maupun masa nifas, asalkan dikonsumsi secara rutin agar peningkatan hemoglobin semakin membaik. Berdasarkan teori, dapat dijelaskan bahwa asam folat dan zat besi yang terkandung dalam buah kurma maupun sari kurma dapat meningkatkan leukosit dan trombosit dalam batas normal (Rakhmawan,2013).

\section{KESIMPULAN}

Ada pengaruh atau efektivitas pemberian sari kurma terhadap peningkatan kadar hemoglobin pada ibu nifas di UPT Puskesmas Kereng Bangkirai Kota Palangka Raya, di dapatkan nilai $p$ - value sebesar 0,000 atau $p$-value $<\alpha(0,005)$, maka dapat disimpulkan bahwa $\mathrm{H}_{0}$ ditolak dan $\mathrm{H}_{\mathrm{a}}$ diterima.

Hasil penelitian ini diharapkan dapat dilanjutkan oleh peneliti lainnya yaitu mengenai efektivitas sari kurma terhadap peningkatan kadar hemoglobin pada ibu nifas dengan indikator penelitian lainnya. Juga diharapkan bisa dijadikan salah satu terapi nonfarmakologis yang diberikan oleh tenaga kesehatan kepada pasien guna meningkatkan kadar hemoglobin pada ibu hamil, maupun nifas. Serta dapat menambahkan wawasan mengenai manfaat dari sari kurma terhadap peningkatan kadar hemoglobin pada ibu nifas sehingga mengurangi terapi famakologi lainnya yang dapat menimbulkan ataupun memberikan efek samping kepala ibu nifas maupun bayinya.

\section{UCAPAN TERIMA KASIH}

Peneliti mengucapkan terima kasih yang sebesar - besarnya kepada Ibu Yuniarti, SST.,M.Kes, Ibu Happy Marthalena Simanungkalit, SST.,M.Keb dan Ibu Asiwei E.Tigoi, SST.,M.Kes.

\section{DAFTAR PUSTAKA}


1. Alfiah Rahmawati dkk.. Pengaruh Konsumsi Kurma (Phoenix Dactylifera) Terhadap Kenaikan Kadar Hemoglobin : A Review. Jurnal Kebidanan.2019

2. Ani, LS. Buku Saku Anemia Defisiensi Besi. Jakarta : EGC.2016

3. Anik M. Asuhan Ibu Nifas dan Asuhan Ibu Menyusui. Bogor : IN MEDIA.2015

4. Dhini Anggraini D, dkk. Hubungan Status Ekonomi dan Status Gizi dengan Kejadian Anemia Pada Ibu Hamil Di Wilayah Kerja Puskesmas Siak Hulu III Tahun 2019. Jurnal Doppler Universitas Pahlawan Tuanku Tambusai Vol 3 No. 2.2019

5. Durrotun Munafiah, dkk. Manfaat Pemberian Mamaku (Madu Kurma Kunyit) Dalam Meningkatkan Kadar Hb lbu Post Partum.Prosiding : Universitas Negeri Semarang.2019

6. Eni, Sendra. Pengaruh Konsumsi Kurma (Phoenix dactylifera L) Terhadap Kenaikan Kadar Hemoglobin pada Ibu Hamil Trimester III di Wilayah Puskesmas. 2016

7. Ester Simanuliang. Modul Askeb Nifas \& Menyusui. Medan: Akademi Kebidanan Mitra Husada.2017

8. Hayu, Isviani. Gambaran Kadar Haemoglobin (Hb) Pada Ibu Hamil Di Wilayar Kerja Puskesmas Ciputat. Jakarta : Universitas Islam Negeri Syarif Hidayatulah.2017.

9. lin, Kusmawati. Pengguna Sari Kurma untuk Meningkatkan Kadar Hemoglobin Ibu Nifas Pada Ny. P Umur 31 Tahun di BPM Djuni Widari Sempor Kebumen. Kabumen : STIKES Muhammadiyah Gombong.2016

10. Retno Widowati, dkk. Pengaruh Pemberian Sari Kurma Terhadap Peningkatan Kadar Hemoglobin Ibu Hamil. Jurnal Al-Azhar Indonesia Seri Sains dan Teknologi, Vol.5 No.2.2019

11. RD Rahayu.. Efektivitas Penambahan Sari Kurma Dalam Pemenuhan Gizi Ibu Hamil Anemia di Puskesmas Wedi, Kabupaten Klaten. Jurnal Kebidanan dan Kesehatan Tradisional, Vol.2 No.2.2017

12. Wiulin Setiowati dkk. Pengaruh Sari Kurma Terhadap Peningkatan Kadar Hemoglobin Ibu Hamil Trimester III. Jurnal Darul Azhar Vol 6 No. 1 Hal 85-91.2018 